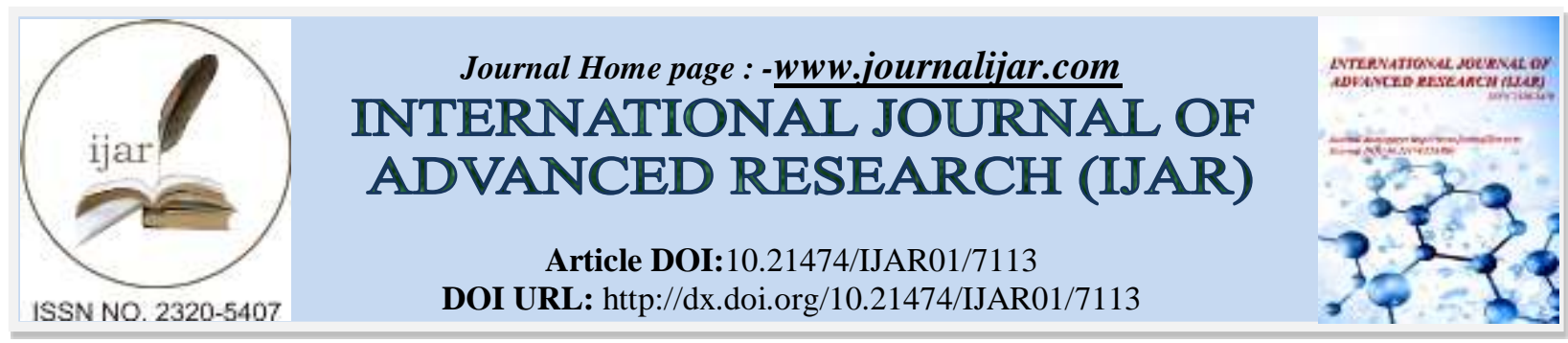

RESEARCH ARTICLE

\title{
NOVEL THERAPEUTIC USE OF INSULIN AND VITAMIN E IN (NAFLD) USING FATTY LIVER INDUCED RATS.
}

\author{
Ingy Badawy ${ }^{1}$, Mahmoud Mohsen ${ }^{1}$, Alaa Ahmed ${ }^{1}$, Shrouk Mahmoud $^{1}$, Amany Saeed ${ }^{1}$, Amr Atef ${ }^{1}$, Al-Taher \\ Rabea $^{2}$, Marina Maurice ${ }^{1}$ and Baher Zlat ${ }^{1}$. \\ 1. Faculty of Biotechnology, Misr University for Science and Technology, Giza, Egypt. \\ 2. R\&D department, Heliopolis University, Cairo, Egypt.
}

\section{Manuscript Info}

Manuscript History

Received: 16 March 2018

Final Accepted: 18 April 2018

Published: May 2018

Keywords:-

Fatty liver, vitamin $\mathrm{E}$ and insulin, NAFLD.

\begin{abstract}
Non-alcoholic fatty liver disease (NAFLD) is the most common liver disorder worldwide. The present study aims to investigate the novel efficacy of both insulin and vitamin $\mathrm{E}$ against fatty liver induced rats. Rats were divided into three groups: control, fatty liver induced, and fatty liver induced treated group received insulin and vitamin $\mathrm{E}$ for ten days. The data revealed a decrease in lipid profile in the treated group in comparison with fatty liver group, also a significant decrease in weight was observed in the treated group compared with the fatty liver group, in addition to a slight improvement in the albumin in the treated group. In conclusion, a combination between both vitamin $\mathrm{E}$ and insulin may be useful for ameliorating lipid profile and decreasing the body weight in the fatty liver rats.
\end{abstract}

Copy Right, IJAR, 2018, All rights reserved.

\section{Introduction:-}

High level of caloric intake has been associated with many diet-induced complications, including metabolic syndrome, cardiovascular disease and non-alcoholic fatty liver disease (NAFLD) (Massiera et al., 2010)

NAFLD is historically considered the hepatic component of MS, and insulin-resistant(IR). It is characterized by loss of the normal inhibition by insulin of adipose tissue. Lack of appropriate insulin-induced suppression of lipolysis translates into elevated plasma fatty acids(FFA) and increased fatty acid uptake by ectopic tissues (muscles, pancreatic beta cells, liver) that results in many of clinical manifestations of the metabolic syndrome and NAFLD (Lomonaco et al., 2012).However, once T2DM is fully developed, it further contributes not only to steatogenesis, but also to progressive liver damage including NASH, fibrosis, cirrhosis, and possibly HCC (Smith et al., 2013). Patients simultaneously affected by T2DM and NAFLD often have poor glycemic control compared to their counterparts without NAFLD (Jimba et al., 2005; Williamsonet al., 2011; and Zoppini et al., 2009). The intrahepatic triglyceride content is the major marker of the amount of insulin needed to achieve good glycemic control in T2DM patients. In fact, in insulin treated T2DM patients with stable glycemic control, the intrahepatic triglyceride content was the factor most strongly correlated with the daily insulin dose, the inter-individual variation in insulin requirements and with the ability of insulin to suppress hepatic glucose production (Ryysy et al., 2000) Many authors suggest that intrahepatic triglyceride content is more important than visceral fat content in inducing adverse metabolic phenotype inobesity (Stefan et al., 2008; Fabbrini et al., 2009 and Gastaldelli et al., 2007) . Taken together, these data have identified NAFLD, not only as one of the more prominent chronic liver diseases, but also 
as a promising, new predictive marker of T2DM, with potential therapeutic implications. Diagnostic and early therapeutic interventions are needed for treating NAFLD patients at risk for developing T2DM. On the other hand, prevention or early diagnosis of progressive liver disease is needed in T2DM patients. In studies to date, intensive insulin therapy has not had anysignificant change in the size of the subcutaneous and visceral fat depots in patients withtype 2 diabetes (Kotronen et al., 2007 and Elsayed et al., 2007). As the popularity of dietary supplements to promote health and prevent disease has increased recently. Vitamin $\mathrm{E}$ is one of the most common antioxidant supplements as it consists of a group of eight molecules belonging to two classes designed as tocopherols and tocotrienols. Vitamin $\mathrm{E}$ is a free radical scavenger that has recently received attention as a potential therapeutic agent to prevent or reduce clinical disease states thought to be associated with excess free radical production (Pruthi et al., 2001).

In the present study, we sought to determine the effects of insulin therapy combined with vitamin E therapy on weight gain, lipid profile and liver enzymes.

\section{Materials and Methods:- \\ Animal design:-}

30 albino rats were purchased and housed in the Center of biological experiments and experimental surgery of the faculty of medicine, Cairo university, the rats were divided into three groups: Group I :included 10 rats as control , fed normal diet, group II: included 10 rats fed high fat diet (HFD) rich in saturated and unsaturated fats and low in carbohydrates ( $60 \%$ fats, $20 \%$ carbohydrates and $20 \%$ proteins) for 6 weeks and group III: included the 10 fatty liver induced rats treated with a combination of vitamin Efor 4 weeks and Insulin(3units for 3 days followed by 1 unit for 7 days)

\section{Sample collection:-}

Blood was collected in EDTA free tubes, clotted for 30 minutes then centrifuged at 5000 rpm for 10-15 minutes. The serum was collected and kept at $-20^{\circ} \mathrm{C}$ until used for the biochemical analyses.

\section{Biochemical tests;-}

Aspartate aminotransferase(AST), alanine aminotransferase (ALT) were carried out using Spectrum Kit (E.C.2.6.1.1 and E.C.2.6.1.2 respectively), Albumin, Urea ,Creatinine ,Total cholesterol and High-density lipoprotein (HDL) were carried out using Biodiagnostic kits for enzymatic colorimetric method. Triglyceride (TG) and glucose were carried out using BioSTC Kit according to the manufacture's protocol.

\section{Statistical analysis:-}

Data were analyzed using SPSS (Statistical Program for Social Science version 17). Quantitative variables were described as mean, SD. The unpaired t-test was used for nonparametric data, Spearman correlation coefficient test was used to rank variables positively or negatively.

$\mathrm{P}$ values greater than 0.05 were considered insignificant; $\mathrm{P}$ values less than 0.05 were considered significant; and $\mathrm{P}$ values less than 0.01 were considered highly significant.

\section{Results:-}

Effect of High Fat Diet on the biochemical parameters:-

Rats subjected to HFD show significant difference in comparison with the control group regarding albumin, Total cholesterol, TG, HDL, iron and glucose as P value was less than 0.05 (Table 1).

The mean values of serum ALT and AST were significantly higher among HFD group (47.69 \pm 23.66 and37.64 \pm 4.527 respectively) compared with control group $(0.5168 \pm 0.2373$ and $0.2168 \pm 0.01641$, respectively) with $\mathrm{P}<0.05$ as shown in Table 1 .

\section{Effect of Vitamin $\mathbf{E}$ and Insulin on the biochemical parameters:-}

Our results show that the treated group (group III) with a combination of vitamin E and insulin show a significant decrease in the lipid profile as compared with group II (before treatment), also the glucose level in group III shows significant decrease as compared with group II but still with significant increased level in comparison with the control group. The AST and ALT are significantly decreased than before treatment,while the albumin level is significantly increased but still less than the control group. 


\section{Effect of Vitamin $E$ and Insulin on the body weight:-}

The body weight decreased significantly in treatment group. The decrease in body weight was $282.6 \pm 43.26 \mathrm{~g}$ in treated group versus $334.8 \pm 9.841 \mathrm{~g}$ in the fatty liver group (before treatment).

But still there is a significant increase in weight in group III when compared with the control group (group I) as shown in table 1.

Table 1:-Body weight and biochemical investigations of the study groups

\begin{tabular}{|l|l|l|l|l|}
\hline & $\begin{array}{l}\text { Group I } \\
\text { N=10 } \\
\text { Mean } \pm \text { SD }\end{array}$ & $\begin{array}{l}\text { Group II } \\
\text { N=10 } \\
\text { Mean } \pm \text { SD }\end{array}$ & $\begin{array}{l}\text { Group III } \\
\text { N=10 } \\
\text { Mean } \pm \text { SD }\end{array}$ & P value \\
\hline Weight (g) & $171.6 \pm 17.76^{\mathrm{bc}}$ & $334.8 \pm 9.841^{\mathrm{ac}}$ & $282.6 \pm 43.26^{\mathrm{ba}}$ & $<0.0001$ \\
\hline AST(U/L) & $0.2168 \pm 0.01641^{\mathrm{bc}}$ & $37.64 \pm 4.527^{\mathrm{a}}$ & $30.77 \pm 13.25^{\mathrm{a}}$ & 0.0002 \\
\hline ALT(U/L) & $0.5168 \pm 0.2373^{\mathrm{bc}}$ & $47.69 \pm 23.66^{\mathrm{ac}}$ & $27.49 \pm 15.82^{\mathrm{ba}}$ & $<0.0001$ \\
\hline Glucose $\mathrm{mg} / \mathrm{dl})($ & $42.30 \pm 26.80^{\mathrm{b}}$ & $96.40 \pm 18.93^{\mathrm{a}}$ & $65.00 \pm 43.34$ & 0.005 \\
\hline Albumin(g/dl) & $3.300 \pm 0.4690^{\mathrm{bc}}$ & $1.970 \pm 0.4620^{\mathrm{a}}$ & $2.200 \pm 0.3559^{\mathrm{a}}$ & $<0.0001$ \\
\hline Iron $(\mathrm{umol} / \mathrm{L})$ & $38.91 \pm 11.25^{\mathrm{bc}}$ & $9.790 \pm 0.9758^{\mathrm{a}}$ & $9.740 \pm 3.490^{\mathrm{a}}$ & $<0.0001$ \\
\hline Cholesterol(mg/dl) & $18.78 \pm 0.1033^{\mathrm{bc}}$ & $44.70 \pm 8.001^{\mathrm{ac}}$ & $33.70 \pm 9.592^{\mathrm{ba}}$ & $<0.0001$ \\
\hline Triglyceride $(\mathrm{mg} / \mathrm{dl})$ & $44.30 \pm 30.93^{\mathrm{b}}$ & $83.10 \pm 31.16^{\mathrm{ac}}$ & $32.60 \pm 36.60^{\mathrm{b}}$ & 0.004 \\
\hline HDL(mg/dl) & $12.18 \pm 3.627^{\mathrm{bc}}$ & $44.03 \pm 6.217^{\mathrm{ac}}$ & $33.40 \pm 9.058^{\mathrm{ba}}$ & $<0.0001$ \\
\hline
\end{tabular}

1. significant from control

2. significant from before treatment

3. significant from after treatment

\section{Discussion:-}

The clinical approach in NAFLD patients is primarily based on lifestyle changes, such as weight loss and physical exercise and is directed towards treating metabolic risk factors associated, such as diabetes, dislipidemia, hypertension (Chalasani et al., 2012). However, many studies have evaluated specific pharmacological therapies, including insulin sensitizers (metformin and thiazolidinediones), weight loss drugs (orlistat and sibutramine), antioxidants (Vitamin E, sylimarin, betaine, pentoxifylline), and have also considered bariatric surgery for morbidly obese patients. Recently, the effects of the new antidiabetic drugs-DPP-4 inhibitors and glucagon-like peptide-1 (GLP-1) analogues - have been evaluated in diabetic NAFLD patients (Van Wagner et al., 2011).

The therapeutic use of antioxidant vitamins has gained considerable interest during the last decade. Previous animal and human studies showed that vitamin E might play a role in preventing the oxidation of polyunsaturated fatty acids in erythrocytes membrane (Elaroussi et al., 2007). In the present study our results reveal that a combination between vitamin $\mathrm{E}$ and insulin play a great role in ameliorating the lipid profile in the treated group in comparison with the fatty liver induced group (Table 1)

Also, as several cytokines as well as ER stress (Kammoun et al., 2009) are involved in NAFLD fibrogenesis, they may represent potential targets (Albanis et al., 2006). However, liver transplantation remains the only curative treatment option for end-stage cirrhosis. More studies are needed in this critical area, with particular focus on treatments, which can reverse or prevent the more advanced and clinically relevant stages of NASH.Among the hepatic enzymes, ALT is most closely related to liver fat accumulation (Kim et al., 2009). Our results agree with the findings of previous studies showing the elevated ALT concentration as an independent predictor of incident nonalcoholic fatty liver disease(NAFLD)(Kim et al., 2009). This finding could be explained by the higher specificity of ALT for liver injury (Lee et al., 2005). Also, as a gluconeogenic enzyme( Kim et al., 2009) increased ALT has been demonstrated to be an indicator of impaired insulin signaling, which might not necessarily be associated with liver injury due to hepatic steatosis.(Kang et al., 2007 and Lee et al., 2008) In our study the liver function enzymes ( AST and ALT) were significantly increased in HFD group as compared with control group meaning that there is a liver injury or inflammation which may be because of the iron-driven free radical production (Table 1). 
Finally, because most studies have been carried out in diabetic patients, new clinical trials must be conducted in non-diabetic patients with early-stage NAFLD, with the aim to investigate the ability of antidiabetic drugs in affecting not only liver steatosis but also T2DM incidence and cardiovascular risk

\section{Conclusion:-}

In conclusion, a combination between both vitamin $\mathrm{E}$ and insulin may be useful for modulating lipid profile, decreasing liver enzymes and decreasing the body weight which affect the liver steatosis in order to prevent the prognosis of the disease.

\section{Competing Interests:-}

Authors have declared that no competing interests exist. The authors alone are responsible for the content and writing of the paper. The authors did not receive any funds from any source

\section{References:-}

1. Albanis, E.; Friedman, S.L. Antifibrotic agents for liver disease. Am. J. Transplant. 2006, 6, 12-19.

2. Chalasani, N.; Younossi, Z.; Lavine, J.E.; Diehl, A.M.; Brunt, E.M.; Cusi, K.; Charlton, M.; Sanyal, A.J. The diagnosis and management of non-alcoholic fatty liver disease: Practice guideline by the American Gastroenterological Association, American Association for the Study of Liver Diseases, and American College of Gastroenterology. Gastroenterology 2012, 142, 1592-1609.

3. Elaroussi,M.A., Fattah,M.A., Meky, N.H., Ezzat,I.E. and Wakwak, M.M. Effects of vitamin E,age and sex on performance of Japanese quil.1. Hematological indices and liver function. Br.Poult. Sci 2007, 48(6):669-677.

4. Elsayed A, ElGebely S, Galal A. Insulin therapy induced adiposity evaluated by computed tomography is no visceral. Pak J Med Sci. 2007; 23(2):161-166.

5. Fabbrini, E.; Magkos, F.; Mohammed, B.S.; Pietka, T.; Abumrad, N.A.; Patterson, B.W.; Okunade, A.; Klein, S. Intrahepatic fat, not visceral fat, is linked with metabolic complications of obesity. Proc. Natl. Acad. Sci. USA 2009, 106, 15430-15435.

6. Gastaldelli, A.; Cusi, K.; Pettiti, M.; Hardies, J.; Miyazaki, Y.; Berria, R.; Buzzigoli, E.; Sironi, A.M.; Cersosimo, E.; Ferrannini, E.; et al. Relationship between hepatic/visceral fat and hepatic insulin resistance in nondiabetic and type 2 diabetic subjects. Gastroenterology 2007, 133, 496-506.

7. Jimba, S.; Nakagami, T.; Takahashi, M.; Wakamatsu, T.; Hirota, Y.; Iwamoto, Y.; Wasada, T. Prevalence of non-alcoholic fatty liver disease and its association with impaired glucose metabolism in Japanese adults. Diabet. Med. 2005, 22, 1141-1145.

8. Kammoun, H.L.; Chabanon, H.; Hainault, I.; Luquet, S.; Magnan, C.; Koike, T.; Ferre, P.; Foufelle, F. GRP78 expression inhibits insulin and ER stress-induced SREBP-1c activation and reduces hepatic steatosis in mice. $J$. Clin. Investig. 2009, 119, 1201-1215.

9. Kang YH, Min HK, Son SM, Kim IJ and Kim YK. The association of serum gamma glutamyltransferase with components of the metabolic syndrome in the Korean adults. Diabetes Res ClinPract 2007, 77:306-313

10. Kim CH, Park JY, Lee KU, Kim JH, and Kim HK. Association of serum gamma-glutamyltransferase and alanine aminotransferase activities with risk of type 2 diabetes mellitus independent of fatty liver. Diabetes Metab Res Rev 2009, 25:64-69.

11. Kotronen A, Juurinen L, Tiikkainen M, Vehkavaara S, Yki-Jrvinen H. Effects of insulin therapy on liver fat content and hepatic insulin sensitivity in patients with type 2 diabetes. Am J PhysiolEndocrinolMetab. 2007; 292(3): E829-35. [PubMed: 17090752]

12. Lee DH and Jacobs DR. Association between serum gamma-glutamyltransferase and C-reactive protein. Atherosclerosis 2005, 178:327-330.

13. Lee MY, Koh SB, Koh JH, Nam SM, Shin JY, Shin YG,Kong ID, Ryu SY, Park JK, and Chung CH. Relationship between gamma-glutamyltransferase and metabolic syndrome in a Korean population. DiabetMed 2008, 25:469-475.

14. Lomonaco R, Ortiz-Lopez C, Orsak B, Webb A,Hardies J, Darland C, Finch J, Gastaldelli A, Harrison S, Tio F, Cusi K. Effect of adipose tissue insulin resistance on metabolic parameters and liver histology in obese patients with NAFLD. Hepatology 2012; 55: 1389-1397.

15. Massiera F, Barbry P, Guesnet P, Joly A, Luquet S, Moreilhon-Brest C, Mohsen-Kanson T, Amri EZ, and Ailhaud G. A Western-like fat diet is sufficient to induce a gradual enhancement in fat mass over generations. $J$ Lipid Res. 2010 ,51:2352-61. 
16. Pruthi, S., Allison, T. and hensrud, D. Vitamin E supplementation in the prevention of coronary heart diseases. Mayo Clin. Proc 2001, 76(11):1131-1136.

17. Ryysy, L.; Hakkinen, A.M.; Goto, T.; Vehkavaara, S.; Westerbacka, J.; Halavaara, J.; Yki-Jarvinen, H. Hepatic fat content and insulin action on free fatty acids and glucose metabolism rather than insulin absorption are associated with insulin requirements during insulin therapy in type 2 diabetic patients. Diabetes 2000, 49, 749758.

18. Smith, B.W.; Adams, L.A. Nonalcoholic fatty liver disease and diabetes mellitus: Pathogenesis and treatment. Nat. Rev. Endocrinol. 2011, 7, 456-465.

19. Stefan, N.; Kantartzis, K.; Machann, J.; Schick, F.; Thamer, C.; Rittig, K.; Balletshofer, B.; Machicao, F.; Fritsche, A.; Haring, H.U. Identification and characterization of metabolically benign obesity in humans. Arch. Intern. Med. 2008, 168, 1609-1616.

20. Van Wagner, L.B.; Rinella, M.E.The role of insulin-sensitizing agents in the treatment of nonalcoholic steatohepatitis.Ther. Adv. Gastroenterol. 2011, 4, 249-263.

21. Williamson, R.M.; Price, J.F.; Glancy, S.; Perry, E.; Nee, L.D.; Hayes, P.C.; Frier, B.M.; van Look, L.A.; Johnston, G.I.; Reynolds, R.M.; et al. Prevalence of and risk factors for hepatic steatosis and nonalcoholic Fatty liver disease in people with type 2 diabetes: The Edinburgh Type 2 Diabetes Study. Diabetes Care 2011, 34, $1139-1144$.

22. Zoppini, G.; Targher, G.; Trombetta, M.; Lippi, G.; Muggeo, M. Relationship of serum gammaglutamyltransferase to atherogenic dyslipidemia and glycemic control in type 2 diabetes. Obesity 2009, 17, 370-374. 